OnLine Journal of Biological Sciences 11 (4): 101-104, 2011

ISSN 1608-4217

(C) 2011 Nedosa and Anastasia, This open access article is distributed under a Creative Commons Attribution

(CC-BY) 3.0 license

\title{
Distribution, Arrangement and Interconnectedness Of Cell Surface Receptor sites in the body of an Organism
}

\author{
Utoh-Nedosa and Uchechukwu Anastasia \\ Department of Pharmacology and Toxicology, Faculty of Pharmaceutical Sciences, \\ Nnamdi Azikiwe University, Awka, Anambra State, Nigeria
}

\begin{abstract}
Cell surface receptors have been identified as the sites of disease infectivity in living organisms in a previous study. Drugs used for the treatment or cure of infections have to eliminate infections through attacking infective organisms at the cell surface receptors to which the infective organisms are attached. Problem statement: The present study examines a wide sample of living things to get more information on the relationship of one cell surface receptor to other cell surface receptors in the body of an organism. Approach: The arrangement of cell surface receptors on the external covering of a few samples of fruits, leaves, stems, dry wood of a plant; wall gecko and some parts of the human body, were examined and photographed. Transverse and/or Longitudinal sections of soursop fruit and sycamore fruit were also examined and photographed. The five different coverings of the fleshy part of a coconut were also photographed. The photographs were studied to note the relationship of disease infection attached to cell surface receptors on the external surface of an organ to disease infection on the innermost covering of the same organ. Results: The results of the study showed that all living things had ubiquitous distribution of cell surface receptors which are usually observable with the unaided eye as dots or spots on the external covering of an organ, tissue or cell. The dots or receptor sites of cell surface receptors in the study are arranged in lines which were perpendicular, oblique, transverse or arranged in any other lineal geometrical form. The lineally arranged cell surface receptors were noted to be connected by grooves, channels or pipes which joined other receptor channels or intersected with them. Smaller cell surface receptor channels emptied into bigger channels or continued as small sized channels that ran side by side in a connective tissue bundle. These connective tissue bundles that carried many independent small-sized cell surface receptor channels joined up to form larger bundles that ran the whole length of the organism. In this way, the cell surface receptors in a locality were interconnect through bigger receptor channel highways to cell surface receptors in other remote parts of the body. This arrangement was illustrated by the sycamore fruit and the soursop fruit. The results of the study also showed that cell surface receptors have functional zonal units with other cell surface receptors which were delimited by cell surface receptor channels. The zoning system of cell surface receptors meant that an infection or a drug treatment of an infection would affect all the cell surface receptors of the same functional unit to the same degree. The cell surface receptor site was raised up when a disease infection at the site was being attacked by a body defence substance of an exogenous drug. Some cell surface receptors were damaged or obliterated or damaged by disease. Examination of different layers of the coconut fruit coverings showed that cell surface receptors traverse all external and internal coverings of an organ or organism no matter the hardness of the covering. They also showed that a disease infection at the outer covering of an organ passes through any number of coverings of that organ to infect the inside of that organ. Cell surface receptors can be destroyed by disease and infective agents still use cell surface receptors to destroy the remains of an organism after the organic death of the organism. Conclusion: From the findings of this study the researcher concludes that cell surface receptors are ubiquitous in living plants and animals; are arranged lineally in receptor channels; have anatomical and physiologic functional units; have a smaller and a bigger reactive head; are the receptors of the main endogenous mediator of an organism's normal body functioning/body's defence and are interconnected by a systematic network of receptor channels.
\end{abstract}

Key words: Infected plant, health problems, fungal infection, receptor channels, organic death, systematic network, innermost covering, cell surface receptors 


\section{INTRODUCTION}

Despite the tremendous advances in modern scientific health care and drug treatment of disease many health problems like diabetes, cancer, tuberculosis and even fungal infections elude total cure and eradication in victims. This fact suggests that there may be some basic facts about health/illness and drug treatment Of disease that still need to be understood. As nature itself is a great teacher, this study examined the patterns of disease infectivity on the body of living things to draw conclusions on the common sites of disease infectivity and their relationship to other parts of the same organ or organism (Abu-Jayyab, 2009; Barret and Blanc, 2009; Gottschalk et al., 2005; Guruswamy and Benbrook, 2006; Hyde and Benbrook, 2006; Kumar, 2009; Lam et al., 2010; Liakou et al., 2007; Lu et al., 2010; Lundholm, 1985; Memo et al., 1985; Menard et al., 2008).

\section{MATERIALS AND METHODS}

Specimens of various healthy and infected plant parts and samples of wood, wall-gecko and parts of the human body were examined with the unaided eye to note the presence or absence of cell surface receptors, the relationship of the cell surface receptors to other cell surface receptors of the same organism [or organ] and the relationship of disease infectivity located in the cell surface receptors of a part of that organism to other parts of that organism.

\section{RESULTS}

A close observation of healthy and infected plant fruits; Stems; leaves; dry wood; coconut fibers, nut, pericarp, mesocarp and endocarp; longitudinally and transversely cut sycamore and soursop fruits; the skin of a wall gecko and human skin in the picture gallery [with the unaided eye] showed that all living things have cell surface receptors [plate1-58]. They also showed that these cell surface receptors were linearly arranged in various directions and were the sites of disease infection of the organism.

They results of the study were also that the cell surface receptors were connected to their neighbors [along the same, linear arrangement] through receptor channels [in which the receptors were immersed]. Larger interconnecting receptor channel pathways connected local receptor channels to other local receptor channels of other parts of the same organism [30-35; 16, 48, 49, 41, 43, 44, 45, 58].
The results of the study also showed that cell surface receptors form functional zonal units with other cell surface receptors. These functional unit zones were delimited by cell surface receptor channels [plates 57 , $41,43,42,55,56,1,2,3,7,6,29,51]$. From the examples shown by the three innermost coverings of the coconut endocarp, a cell surface receptor can form functional units with many cell surface receptors which are some distant away from it. This zoning system of cell surface receptors showed that an infection affected all the cell surface receptors of the same functional unit to the same degree. Similarly, a drug applied to a cell surface receptor functional unit, was sent to reach all the cell surface receptors in that functional at the same time $[50,19]$.

Comparism of disease-infected and healthy parts of living organisms studied showed that the infected cell surface receptor site was usually raised up (sometimes with a red flare) [plate 4, 5, 48, 24, 25, 26, 55, 56, 52].

The disease infection patterns on the different layers of the coconut fruit coverings [plate 37, 38, 39, $40,42,43$ showed that cell surface receptors traverse all external and internal coverings of an organ or organism no matter the hardness of the covering. It also showed that a disease infection at the outer covering of an organ or tissue that is enclosed in many coverings infects every one of the coverings in exactly the same pattern.

The disease infection and wood plank destruction patterns seen in plates $10,11,12,13,14$ and 15 demonstrated that an organ/ organism is destroyed along the cell surface receptors and their channels. They also demonstrated that an organism is finally decimated by destructive action of infective agents attached to the cell surface receptors of the remains of that organism after the organism has undergone organic death.

The cell surface receptor site was found to have two reactive heads marked 1, 2 in plates 53, 26 and 28.

\section{DISCUSSION}

A study noted that dihydroartemisinin interacted with specific parasite proteins. This is an indication that dihydroartemisinin interacted with cell surface receptors on the parasite membrane. A number of studies have connected the development of organ toxicity (Tripathi et al., 2010) and cancer to certain receptors (Sato et al., 2005; Seggewiss et al., 2008; Weshi et al., 2007; Mustjoki et al., 2007; Filipovich et al., 1994; Suzuki et al., 2005; Galustian et al., 2009; Farag et al., 2002; Morre et al., 2008). These receptors involved in organ toxicity; in cancer or in other body 
disorders/diseases are cell surface receptors (UtohNedosa and Anastasia, 2011).

The findings of this study confirm that all living plants and animals maintain the status of being alive through the normal and defensive actions of an endogenous body defence substance on its receptors which are cell surface receptors (Utoh-Nedosa and Anastasia, 2011). These receptors are strategically placed on the surface of coverings of an organ, a tissue or a cell to fence off biochemical or physical agent that endanger the life of an organism.

Another previously unknown finding of this study is that cell surface receptors have anatomical functional units and can operate in several functional units. A study in rats with dihydroartemisinin showed that dihydroartemisinin made two types of inhibitory occupations on the cells of the heart muscles; a $\mathrm{B}_{1}$ adrnoceptor occupation of the myocardium and the cells of the smooth muscles lining the walls of coronary blood vessels; and a $\mathrm{B}_{2}$-adrenorceptor occupation of nodal tissues and haemopoietic stem cells of the heart (Anastasia et al., 2011). These findings confirm that cell surface operate in functional units. The present study confirmed that o reactive heads and that the size of one of the reactive heads is half the size of the other reactive head [plate 53].

\section{CONCLUSION}

The conclusions of this study about cell surface receptors are that cell surface receptors:

- Ubiquitous in living plants and animals

- Arranged lineally in receptor channels

- Anatomical and physiologic functional units and delimited zones

- One smaller and one bigger reactive head

- The receptors of the main endogenous mediator of an organism's normal body functioning and mediator of body's defense

- Interconnected by well organized systematic network of receptor channels

\section{REFERENCES}

Abu-Jayyab, A., 2009. Involvement of microsomal $\mathrm{Na}+\mathrm{K}+$ ATPase activity in the mechanism of action of dopaminergic D2 receptors. Am. J. Pharmacol. Toxicol., 4: 158-164. DOI: 10.3844/ajptsp.2009.158.164
Anastasia, U.N.U., A.P. Achunike, N.K. Stanislaus, O.I. Kenneth and N.I. Valentine et al., 2011. Two types of inhibitory occupation and activity of oral dihydroartemisinin on cardiac muscles of wistar albino rats. Inventi Journals Pvt. Ltd.

Barret, J. and K.L. Blanc, 2009. Cancer chemotherapy and immune regulation. Am. J. Immunol., 5: 8-16. DOI: $10.3844 /$ ajisp.2009.8.16

Farag, S.S., T.A. Fehniger, L. Ruggeri, A. Velardi and M.A. Caligiuri, 2002. Natural killer cell receptors: new biology and insights into the graft-versusleukemia effect. Blood, 100: 1935-1947. PMID: 12200350

Filipovich, A.H., A. Mathur, D. Kamat, J.H. Kersey and R.S. Shapiro, 1994. Lymphoproliferative disorders and other tumors complicating immunodeficiencies. Immunodeficiency, 5: 91112. PMID: 8032367

Galustian, C., B. Meyer, M.C. Labarthe, K. Dredge and D. Klaschka et al., 2009. The anti-cancer agents lenalidomide and pomalidomide inhibit the proliferation and function of $\mathrm{T}$ regulatory cells. Cancer Immunol. Immunother., 58: 1033-1045. PMID: 19009291

Gottschalk, S., H.E. Heslop and C.M. Rooney, 2005. Adoptive immunotherapy for EBV-associated malignancies. Leuk Lymphoma, 46: 1-10. PMID: 15621775

Guruswamy, S. and D.M. Benbrook, 2006. Retinoids chemosensitize ovarian cancer cell lines to cisplatin independent of nuclear receptors and p53. Am. J. Pharmacol. Toxicol., 1: 87-93. DOI: 10.3844/ajptsp.2006.87.93

Hyde, J. and D.M. Benbrook, 2006. Sensitivities of uterine adenocarcinoma, Mixed Mullerian Tumor (MMT) and sarcoma cell lines to chemotherapeutic agents and a flex-het drug. Am. J. Pharmacol. Toxicol., 1: 83-86. DOI: 10.3844/ajptsp.2006.83.86

Kumar, R.M., 2009. The widely used diagnostics "DNA Microarray"-A review. Am. J. Infect. Dis., 5: 207-218. DOI: 10.3844/ajidsp.2009.207.218

Lam, H.Y., S.K. Yeap, N.B. Alitheen, W.Y. Ho and A.R. Omar et al., 2010. Understand the role of natural killer. Am. J. Immunol., 6: 54-61. DOI: 10.3844/ajisp.2010.54.61

Liakou, C.I., S. Narayanan, D.N. Tang, C.J. Logothetis and P. Sharma, 2007. Focus on TILs: Prognostic significance of tumor infiltrating lymphocytes in human bladder cancer. Cancer Immunol., 7: 1-10. Lu, D.Y., X.L. Chen, M. Huang, B. Xu and J. Ding, 2010. Relationship between blood fibrinogen concentration and pathological features of cancer patients: A 139-case clinical study. OnLine J. Biol. Sci., 7: 8-11. DOI: 10.3844/ojbsci.2007.8.11 
Lundholm, C.E., 1985. Relation between Ca metabolism and ATPase activities in the subcellular fractions from duck eggshell gland mucosa after DDE administration during different stages of eggshell formation. Comp. Biochem. Physiol. C., 82: 1-16. PMID: 2865048

Memo, M., E. Carboni, M. Trabucchi, M.O. Carruba and P.F. Spano, 1985. Dopamine inhibition of neurotensin-induced increase in $\mathrm{Ca}_{2}{ }^{+}$influx into rat pituitary cells. Branin Res., 347: 253-257. PMID: 2415214

Menard, C., F. Martin, L. Apetoh, F. Bouyer and F. Ghiringhelli, 2008. Cancer chemotherapy: Not only a direct cytotoxic effect, but also an adjuvant for antitumor immunity. Cancer Immunol. Immunother., 57: 1579-1587. PMID: 18369619

Morre, D.J., S. Dick, E. Bosneaga A. Balicki and L.Y. $\mathrm{Wu}, 2008$. tNOX (ENOX2) target for chemosensitization-low-dose responses in the hormetic concentration range. Am. J. Pharmacol. Toxicol., 3: 19-29. DOI: 10.3844/ajptsp.2008.19.29

Mustjoki, S., T. Lundan, S. Knuutila and K. Porkka, 2007. Appearance of bone marrow lymphocytosis predicts an optimal response to imatinib therapy in patients with chronic myeloid leukemia. Leukemia, 21: 2363-2368. PMID: 17568811

Sato, E., S.H. Olson, J. Ahn, B. Bundy and H. Nishikawa et al., 2005. Intraepithelial $\mathrm{CD} 8^{+}$tumorinfiltrating lymphocytes and a high $\mathrm{CD}^{+} /$regulatory $\mathrm{T}$ cell ratio are associated with favorable prognosis in ovarian cancer. Proc. Natl. Acad. Sci., 102: 18538-18543. DOI: 10.1073/pnas.0509182102
Seggewiss, R., D. Price and M. Purbhoo, 2008. Immunomodulatory effects of imatinib and secondgeneration tyrosine kinase inhibitors on T cells and dendritic cells: An update. Cytotherapy, 10: 633641. DOI: $10.1080 / 14653240802317639$

Suzuki, E., V. Kapoor, A.S. Jassar, L.R. Kaiser and S.M. Albelda, 2005. Gemcitabine selectively eliminates splenic $\mathrm{Gr}-1^{+} / \mathrm{CD} 11 \mathrm{~b}^{+}$myeloid suppressor cells in tumor-bearing animals and enhances antitumor immune activity. Clin. Cancer Res., 11: 6713-6721. DOI: 10.1158/10780432.CCR-05-0883

Tripathi, T., A.A. Khan, M. Shahid, H.M. Khan and M. Siddiqui et al., 2010. Hepatotoxicity due to histamine trifluoro-methyl toluidide, amthamine, R-(-)- $\alpha$-methyl histamine and clobenpropit (H1RH4R-agonists, respectively) in rabbit experimental model. Am. Med. J., 1: 1-7. DOI: 10.3844/amjsp.2010.1.7

Utoh-Nedosa, and U. Anastasia, 2011. Cell surface receptor theory of disease infectivity; body's defence and normal body functioning in living things. Online J. Biol. Sci., 11: 76-83. DOI: 10.3844/ojbsci.2011.76.83

Weshi, A.E., S. Akhtar, W.A. Mourad, D. Ajarim and M. Abdelsalm et al., 2007. T-cell/histiocyte-rich Bcell lymphoma: Clinical presentation, management and prognostic factors: Report on 61 patients and review of literature. Leuk Lymphoma, 48: 17641773. PMID: 17786712 